\section{Impact of Land Degradation on Rural Livelihoods in Sub- Saharan Africa}

\author{
Genesis Tambang Yengoh \\ Lund University Centre for Sustainability \\ Studies - LUCSUS, Lund University, \\ Lund, Sweden
}

\section{Definitions}

Land degradation refers to the human-induced processes that drive the decline or loss in biodiversity, ecosystem functions, or ecosystem services in any terrestrial and associated aquatic ecosystems (IPBES 2018).

Land Degradation Neutrality (LDN) is a state whereby the amount and quality of land resources necessary to support ecosystem functions and services and enhance food security remain stable or increase within specified temporal and spatial scales and ecosystems (UNCCD 2016). This is a condition where further land degradation (loss of productivity caused by environmental or human factors) is prevented and already degraded land can be restored.

Livelihoods are the methods and means of making a living in the world - a concept revolving around resources such as land, property, food, knowledge, finances, social relationships, and their interrelationships with the political, economic, and sociocultural characteristics of an individual community (Islam and Ryan 2015).

Sustainable Land Management (SLM) was defined at the Rio Earth Summit of 1992 as the use of land resources, including soils, water, animals, and plants, for the production of goods to meet changing human needs, while simultaneously ensuring the long-term productive potential of these resources and the maintenance of their environmental functions. SLM brings together practices and technologies that integrate the management of environmental resources (land, water, biodiversity, and others) to meet human needs while ensuring the long-term sustainability of ecosystem services and livelihoods.

\section{Introduction}

The region of sub-Saharan Africa is made up of 54 countries and has a population that currently stands at about 1.078 billion with an annual growth rate of about $2.6 \%$ (United Nations Department of Economic and Social Affairs Population Division 2019). While the population of the region is not evenly distributed, there are certain characteristics of its demography that are common for most countries. For example, the population is generally a very youthful one, with $42.5 \%$ aged below 14 years, $54.5 \%$ of $15-$ 64 years, and just about $2.9 \%$ above the age of 65 years (United Nations Department of Economic and Social Affairs Population 
Division 2019). The rate of urbanization is rapid, at about $3.98 \%$ per annum, with the urban population as a percent of the total population in the region constituting about $40.1 \%$. To put in perspective, the average annual rate of change of the percentage urban population in Asia between 2015 and 2020 is $2.16 \%$, Europe $0.35 \%$, Latin America $1.30 \%$, and North America 0.95\% (United Nations Department of Economic and Social Affairs Population Division 2018). From a socioeconomic perspective, the region is the poorest in the world, with an estimated one in every three people living below the poverty line. While more than half of the world's extreme poor live in sub-Saharan Africa, it must be observed that in recent years (2000-2015), several African countries have made impressive gains in reducing extreme poverty (Beegle and Christiaensen 2019). Examples of such countries include Tanzania, Chad, and the Republic of Congo. Currently, poverty in sub-Saharan Africa is heavily concentrated in just 10 countries (Nigeria, D.R. Congo, Ethiopia, Tanzania, Kenya, Madagascar, Mozambique, Uganda, Zambia, and Malawi), which make up over $70 \%$ of the region's poor (Beegle and Christiaensen 2019).

Agriculture is the main sector of employment in sub-Saharan Africa, accounting for 54\% (International Labour Organization 2020). Here, and other parts of the developing world, small-scale farmers carry out about $60 \%$ of the agricultural activities and contribute to the production of about $80 \%$ of the food, hence playing a leading role in ensuring food security not only in developing countries, but globally as well (IOM and UNCCD 2019). The relationship between the quality and quantity of land and the production as well as productivity of smallholder agriculture is a very close one, and given the role this group of agricultural producers play in the overall food production, also a very important one. Throughout sub-Saharan Africa, land is the major natural resource that lays the foundation for economic, social, and cultural development, and the livelihood of rural communities is seriously threatened when the condition of land is negatively altered. Land degradation diminishes the quality of land, and affects the quantity of productive land that is available for use in food production and the provision of ecosystem services in a pervasive and systemic manner. It can take many problematic forms, such as: physical deterioration, chemical contamination, salinity, deforestation, desertification, soil erosion, nutrient depletion, and overgrazing (Stocking and Murnaghan 2001).

Policy and institutional responses to the pressures on land and water resources at the national level have been suffering from inadequate financing, poor targeting challenges relevant to land improvement, poor coordination among key stakeholders, and the malign influence of national and international private sectors stakeholders. In some cases, insufficient engagement of local populations in the design and implementation of project constitute major hurdles. The competence and effectiveness of governance to address pressures on land and water resources (or indeed the use and sustainable management of many other natural resources) has also been called into question, as corruption, impunity, and the lackluster approach to dealing with major natural resources issues has been evident at different levels of natural resource governance in the region. The result has been a degradation of land in many countries and parts of the region, a decline of the quantity and quality of ecosystem services resulting from this degradation, and further pressure on existing land resources (Global Mechanism of the UNCCD et al. 2019).

Many studies have estimated the extent of degradation in sub-Saharan Africa. There has not been consensus on the exact extent and severity of land degradation for different landscapes and ecosystems. This lack of consensus stems from the types of methods and datasets used, paucity of data, differences in analysis periods, spatial units of analysis, and differences in the definition of operational variables. Nonetheless, there is strong agreement that land degradation in the region is a serious problem. The FAO describe the rate of progression of land degradation in Africa and its reach as "alarming" (FAO and ITPS 2015). It is estimated that the effects of land degradation affected more than half of the continent's total population, equivalent to 621 million people, $55 \%$ (343 million) living in rural areas in the region (Global Mechanism of the UNCCD et al. 2019). 


\section{Definition of Land Degradation}

The rapid degradation of land is often the result of a broken economic system, characterized by an inefficient food production system, combined with other land polluting and degrading practices which usually achieve short-term economic returns that tend to benefit a few, at the expense of many (UNCCD 2017). In sub-Saharan Africa in particular, demographic pressure and the struggle to produce more using poor land use practices in order to satisfy growing food needs are among the key drivers of land degradation in the predominantly rain-fed agricultural lands of its arid, semiarid, and subhumid areas. Some of these land use practices include among other: (1) The open-loop nutrient system that results in the inadequate restitution of plant nutrients to the land; (2) Absence of fallows or the existence of fallows that are not properly managed to replenish depleted soil nutrients; (3) Inability to repair and sustain physical barriers to land degradation (such as soil erosion prevention terraces) as a result of declining labor supplies in rural area; (4) Poor levels of croplivestock integration; and (5) Encroachment of farming into areas where risk of drought is high or on to other marginal lands.

Land degradation generally leads to the disruption of a healthy balance between key ecosystem functions, such as, carbon capture and sequestration, food production, water retention and the recharge of underground water supplies, the provision of fiber, and microclimate regulation. While land degradation is prevalent and persistent in all landscapes of the African continent (see Fig. 1), the African drylands are among some of the most vulnerable to degradation, and the challenge has come under sharp focus by various initiatives and researchers. The United Nations Convention to Combat Desertification's (UNCCD) reports that the African continent is home to the largest populations rural population living on degraded drylands ( $45 \%$ of 444 million people worldwide) (Global Mechanism of the UNCCD et al. 2019). Of this population of Africans living in degraded drylands, about $61 \%$ reside on degraded rural drylands, constituting $46 \%$ on rural hyperarid drylands, and $26 \%$ on semiarid drylands.
Given its huge importance for ecosystems, human well-being and sustainable development, the onset of international level institutional efforts to address land degradation dates back several decades. For example, the concept of Sustainable Land Management was formally recognized at the Rio Earth Summit of 1992. The same persisting concern has led to the development of the concept of Land Degradation Neutrality (LDN) by the UNCCD, and a LDN Scientific Conceptual Framework that was developed and endorsed by UNCCD Member States in September 2017 (Cowie et al. 2018).

\section{Land Degradation in the Sustainable Development Goals}

Land remains the most fundamental asset for the majority of vulnerable populations living in developing countries, as their livelihoods are directly linked to agriculture. When desertification, land degradation and drought (DLDD) disrupt these livelihoods, low productivity of agricultural lands and a decline in the quantity and quality of ecosystem services that supports rural populations becomes the inevitable outcome in communities that usually benefit from limited or almost no support from regional or national governments. To escape the poverty and destitution that sets it, migration is often the only option that remains (IOM and UNCCD 2019). In 1994, the United Nations Convention to Combat Desertification (UNCCD) recognized that desertification and drought affect sustainable development through their interrelationships with important social problems. Such problems include among others, poverty, poor health and nutrition, lack of food security, and those arising from migration, displacement of persons, and demographic dynamics.

The challenge of land degradation is addressed under Sustainable Development Goal (SDG) 15 Life on Land. Target 15.3 sets out a new global ambition, which is at the heart of the battle to address land degradation, the degradation of ecosystems, and the services they provide. It states that "By 2030, combat desertification, restore 

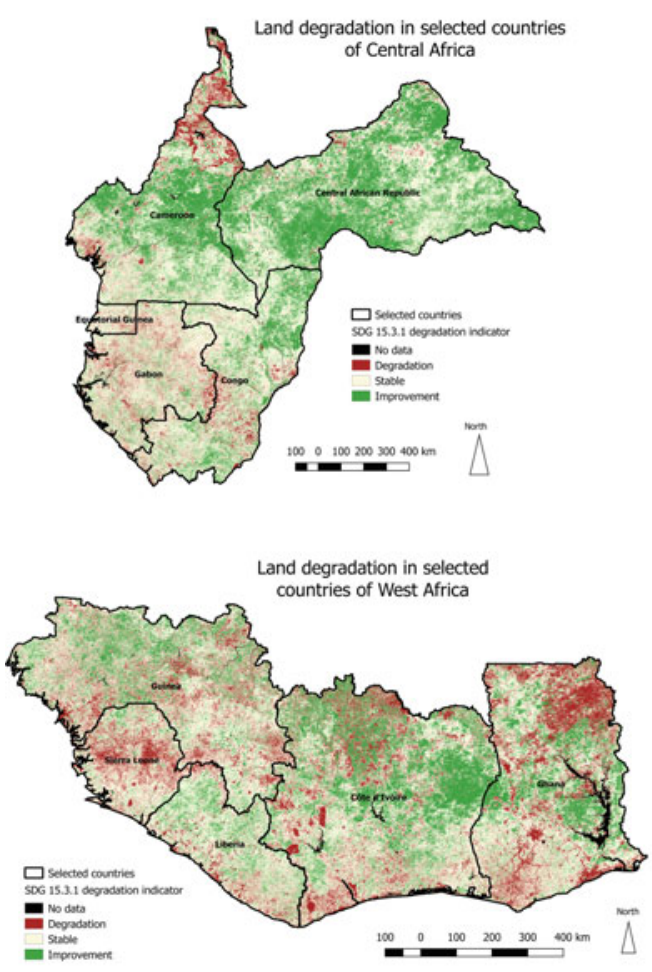
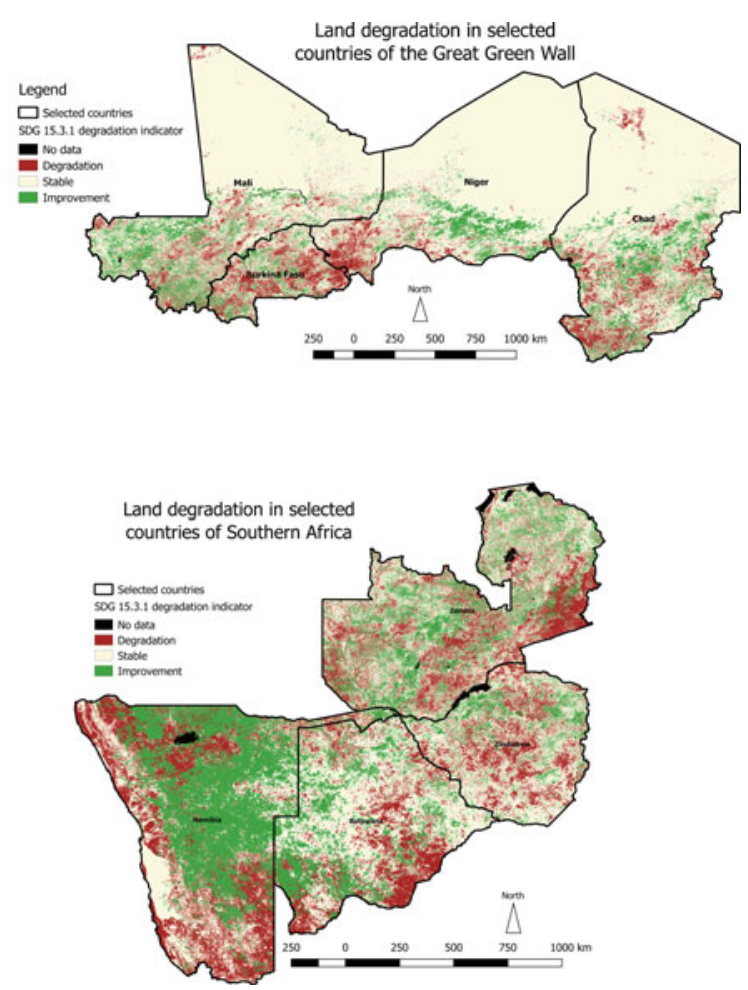

Impact of Land Degradation on Rural Livelihoods in Sub-Saharan Africa, Fig. 1 Land degradation in selected countries of Central, West, Southern Africa, as well as countries of the Great Green Wall Initiative. The assessment is done using methodology reported in Zvoleff et al. (2018)

degraded land and soil, including land affected by desertification, drought, and floods, and strive to achieve a land-degradation-neutral world." To quantify this Target, a Working Group was established to define relevant indicators for monitoring progress toward what has become known as the LDN target (Indicator 15.3.1: "Proportion of land that is degraded over the total land area"). The working group agreed on three main subindicators to track land degradation and to derive the spatial extent and thus the percentage of total land that is degraded. These include (1) land cover and land cover change, (2) land productivity, and (3) carbon stocks, above and below ground, which can be used for monitoring and reporting progress towards SDG target 15.3 (Cowie et al. 2018).

To date, LDN targets have been set and endorsed on a voluntary basis by almost all countries of the sub-Saharan Africa region, as part of their obligations under UNCCD and in connection with their commitments to UNFCCC, as well as to the CBD. As part of the LDN approach, a specific LDN impact investment Fund (LDN Fund) was established to support private investment in economically viable Sustainable Land Management (SLM) projects, in complement to existing and developing public investment funds operating inter alia with cofinancing from Global Climate Fund (GCF).

There are strong and direct interlinkages between SDG 15 (life on land) and other SDGs, such as SDG 1 (no poverty); SDG 2 (zero hunger); SDG 5 (gender equality); SDG 11 (sustainable cities and communities); SDG 13 (climate action); and SDG 14 (life under water). While all the SDGs are important in themselves and for the achievement of the others, SDG 15 can be seen as a central or foundational SDG between all others - especially in the context of sub-Saharan Africa where land and land-based resources are at the center of almost all development efforts. 
Hence, working to achieve SDG 15 would provide enabling conditions for achieving many others. Figure 2 shows some of the SDGs whose achievement is directly linked to progress in SDG 15. While the central role of SDG 15 is particularly pertinent as described above, one should not lose sight of the fact that all SDGs do complement each other in the form of indispensable pieces in a big and complex puzzle.

\section{Implications of Land Degradation for Rural Livelihoods in SSA}

The definition of livelihoods provided by Islam and Ryan (2015) indicates that livelihoods are determined by multiple factors and depend on a combination of different assets. Land resources fall under the category of natural assets, which comprise natural resource stocks, which people can access and use to build their livelihoods (forests and water resources also fall in this category), or physical assets which refer to tangible assets that can be owned by a person, household community or enterprise. Other physical assets that are common in rural areas of sub-Saharan Africa besides land may include livestock, farm tools, roads, etc.

Given the huge size of the region, it is reasonable to expect variations in the impact of land degradation on livelihoods. Indeed, the socioeconomic impacts of land degradation vary with the geographical, political, and economic context (ELD Initiative and UNEP 2015). Nonetheless, some generalities that can be drawn may apply for a vast majority of countries and rural areas in the region. Here the focus of the impact of land degradation will be on rural food security, environmental resources, poverty, ecosystem services, the gendered dimension of impacts, and on health.

\section{Land Degradation and Rural Food Security}

Though about $54 \%$ of the population is engaged in agriculture in sub-Saharan Africa (International Labour Organization 2020), much of the region still suffers from some sort of food and/or nutrition insecurity. The demand for food is putting greater pressures on the natural resource base, with land and water being among the resources under the most pressure from this demand. While the majority of the world's hungry people live in developing countries, Sub-Saharan Africa alone remains the region with the highest prevalence of hunger, with the rate increasing from $20.7 \%$ in 2014 to $23.2 \%$ in 2017 (United Nations Organization 2015). Here, in 2017, the number of undernourished people increased from 195 million in 2014 to 237 million.

One of the most evident impact of land degradation to rural populations in sub-Saharan Africa is the impact on food production and security. Land degradation can negatively affect food security both directly and indirectly by influencing food production (through it influence on soil fertility and agro-biodiversity), but also its distribution and accessibility (through its impact on transport systems and food distribution efficiency). Food production, specifically crop yields depend on a number of soil elements such as nutrient content, water holding capacity, organic matter content, soil $\mathrm{pH}$, top soil depth, salinity, and others. Processes affecting such characteristics can potentially reduce crops yield, thus food production. Physical and chemical forms of land degradation do affect these characteristics on agricultural lands.

Degradation of soil conditions is probably the most widespread and pernicious form of deterioration, because it affects a major life-supporting system and because its natural regeneration may take centuries. Artificial soil rehabilitation or amelioration is often very expensive, and beyond the reach of many rural smallholder agricultural producers. It must be noted though that the relationship between soil degradation and crop yields, however, is seldom straightforward. Productivity can be affected by many factors, such as the weather, disease and pests, farming methods, external markets, and other economic forces (Hori et al. 2011). Soil fertility decline is a feature of much of the smallholder agricultural experiences in rural African landscapes. Sub-Saharan Africa remains one of the regions with the lowest use of inorganic fertilizer amendments to improve soil fertility in the world (FAO 2020). Many farmers in SSA have developed soil management 


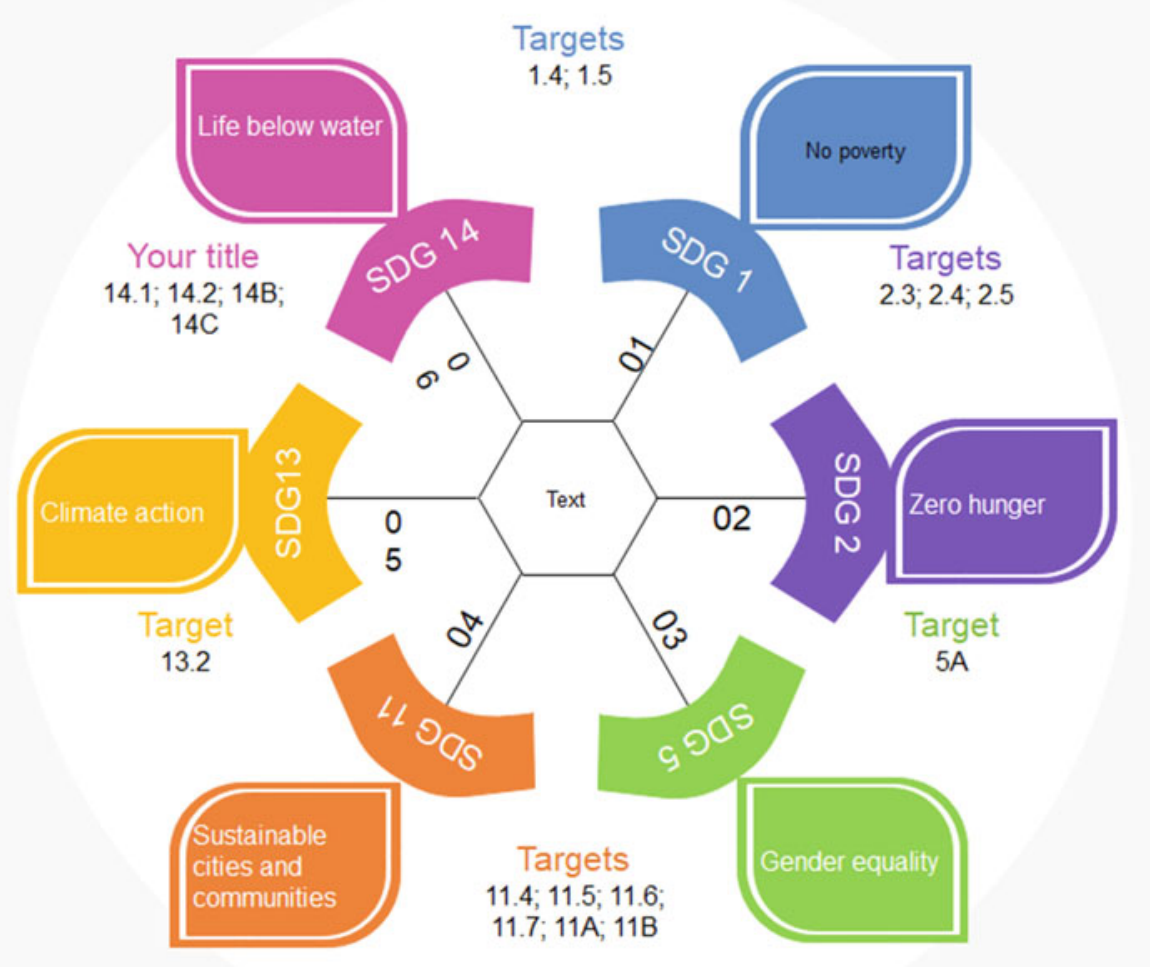

Impact of Land Degradation on Rural Livelihoods in Sub-Saharan Africa, Fig. 2 Other key SDGs in sub-Saharan Africa with which SDG 15 has direct relationships and the Targets directly involved

strategies to cope with the poor quality of their soil. These strategies vary in complexity, cost, effectiveness, and their ability to be sustained. Notwithstanding substantial challenges to soil health, including low inputs of nutrients and organic matter, the open loop systems of nutrient management and the poor integration of crop and livestock systems continue to contribute to poor crop growth and the depletion of soil nutrients.

The burden of land degradation is disproportionately borne by smallholder farmers, who depend on these lands to produce food for their families, local communities, and most urban areas in the region. The toll of land degradation on food security and rural income generation is huge. For example, Gashu and Muchie (2018) reported that in the Chilga district of Northwest Ethiopia, more than $80 \%$ of the respondents reported that land degradation has impacts both on crop yield and livestock production. At the scale of the African continent, a total production of about 280 million tons of cereal crops per year from about 105 million hectares of croplands is being lost as a result of land degradation (ELD Initiative and UNEP 2015). It was estimated that in some areas of the region, agricultural productivity declined by half between 1981 and 2003 as a result of soil erosion and desertification processes (Eswaran et al. 2001). 


\section{Land Degradation and the Supply of Key Livelihood-Support Resources}

Forests and dryland landscapes provide a range of resources that are directly vital to livelihoods in sub-Saharan Africa. These include, among others, energy resources, non-timber forest products, protein sources, timber, medicinal plants, water sources, and many others. Land degradation directly affects the quantity and quality of these resources with the potential of reducing the ability of rural populations to sustain their livelihoods, and in worse cases, generate conflicts over these resources.

Energy resources: Wood fuel (and its immediate derivatives such as charcoal) is the principal source of domestic energy for cooking and lighting both in rural and urban populations of subSaharan Africa. In 2010, the FAO estimated that globally, more than two billion people depend on wood energy for cooking and heating, particularly in households in developing countries (FAO 2010a). This study reported that in many parts of Africa, wood fuels are usually often the only domestically available and affordable sources of energy, and account for about $90 \%$ of primary energy consumption. The FAO also estimates that by 2030 , about $75 \%$ of total residential energy in sub-Saharan Africa will biomass energy (FAO 2010b). At a country level, Eba'a et al. (2016) calculated that urban areas of Cameroon (with a comparatively better energy mix that rural areas) consumed about 2.2 million metric tons of firewood and 356,530 metric tons of charcoal annually. The study found that firewood and charcoal contribute to the GDP for an estimated amount of US\$ 304 million representing 1.3\% of the GDP of Cameroon. Land degradation (through for example deforestation or unsustainable harvesting of wood for fuel) continues to push the forest margins and distances to access these resources in many countries of the region, leading to limited supplies and prices increases that affect the ability for rural communities and some urban dwellers to afford them.

Non-timber forest products (NTFPs): The majority of populations (especially rural communities and households) of Sub-Saharan Africa's rely on forest products for subsistence uses, cash income, or both (Heubach et al. 2011). In Benin for example, Heubach et al. (2011) found that net income from NTFPs reflects traditional sources of livelihoods of different ethnic groups, and that on average, income from NTFPs accounted for 39\% of total household income and had a strong equalizing effect on it. The study noted that poorer households were relatively more dependent on NTFPs in order to fulfil basic needs than wealthier households. In south Africa, it was found that the value NTFPs to rural households includes cost saving to the families from the alternatives to NTFPs that would have been bought, as well as serves as an insurance in times of misfortune, such as drought, disease, and unexpected economic hardship (Shackleton and Shackleton 2004). Healthy forests, sustainable harvesting, and pragmatic management are the elements that sustain the supply of NTFPs, which means that forest degradation has the potential to reduce and destroy these resources.

Wild animal protein: Across many parts of subSaharan Africa, wildlife harvesting and consumption (in the form of bushmeat) provides a source of food and income (Vega et al. 2013; Wilkie et al. 2016). The harvest of animals such as tapir, duikers, deer, pigs, peccaries, primates, and larger rodents, birds, and reptiles provides benefits to local people worth millions of US\$ annually and represents around six million tons of animals extracted yearly (Nasi et al. 2011). Rural populations tend to be more heavily dependent on wild protein resources than their urban counterpart whose ability to procure alternative protein sources may be higher given generally higher incomes (Wilkie et al. 2005). Bushmeat consumption is very important for rural diets. The FAO reports that in Central Africa, rural consumption of bushmeat ranges from 14.6 to $97.6 \mathrm{~kg} / \mathrm{capita} /$ year and hunting provides between $30 \%$ and $80 \%$ of the overall protein intake of rural households and nearly $100 \%$ of animal proteins. In rural Ghana, bushmeat consumption accounts for $75 \%$ of the animal protein sources, and to as much as $80-90 \%$ in Liberia (FAO 2015). For rural communities, bushmeat consumption sometimes serves as a safety net in lean times. For example, Brown and Williams (2003) reported that in 
Eastern DRC, consumption of wild foods increases significantly during the hungry season (particularly bushmeat, where consumption rose on average by $75 \%$ ). Bushmeat is also important as an income source for local communities living in the vicinity of wild spaces and in some cases, protected and conserved areas. In a study of comparing the livelihoods and protein intake between commercial and subsistence bushmeat hunters in Equatorial Guinea, Vega et al. (2013) found that commercial hunters generated a mean of US\$2000/year from bushmeat sales. The study also reported that households with commercial hunters were on average wealthier, generated more income, spent more money on nonessential goods, and bought more products they did not grow. By contrast, households with subsistence hunters spent less on market items, spent more on essential products, and grew more of their own food. Notwithstanding their value for local livelihoods and nutrition, the scale of current hunting is a serious threat to many forest species and ecosystems (Barychka et al. 2020; Nasi et al. 2011). Local extirpation of hunted species is widespread, with West and Central Africa particularly affected (Milner-Gulland and Bennett 2003). Many large animals have already gone ecologically extinct in vast areas of neotropical forest areas (Fa et al. 2015; FAO 2015). Land degradation (such as deforestation) will have the same effects on bushmeat availability and consumption as it will have on the availability and use of other NTFPs, with a disproportionate burden being felt by rural communities who depend the most on these sources of protein and income source.

\section{Land Degradation and Rural Poverty}

While consensus has not been definitively reached in establishing the relationship between land degradation and poverty at a general level, strong connections between land degradation and poverty in rural areas have been apparent for a while. Turner et al. (1994) observed that the inter-linkages between land degradation and poverty would be strong in the rural areas of low-income countries where livelihoods predominantly depend on agriculture. The relationship between land degradation and poverty is not a linear one, instead it originates from a set of underlying and proximate drivers that initiate and sustain a series of reinforcing conditions for land degradation leading to poverty, and poverty in turn further perpetuating land degradation.

Rapid population growth and urbanization are some of the main underlying drivers of increased demand for environmental resources in sub-Saharan Africa. These drivers lead to increased demand for resources such as agricultural land (for crops and livestock), fuelwood, building materials, and land for habitation. These demands are satisfied in many cases through the encroachment and acquisition of new hitherto intact land or land with limited degradation and in some cases through the overexploitation of resources from land- and waterscapes. This is achieved through the clearing of natural forests (deforestation) or other forms of conversion. In the case of land for agricultural production, the resource-limited conditions that characterize agricultural land use in sub-Saharan Africa imposes land management and production methods that generally lead to declines in productivity in agricultural lands. In cases where the land is used to satisfy needs for fuel, as either wood or charcoal, the land is rapidly depleted of its protective vegetative cover and succumbs to rapid erosion. In cases where the land is used for the expansion of habitable areas, poor land use and urban planning fail to adequately protect the land from the downsides of human population and infrastructure expansion (poor approaches to waste disposal, inadequate greening of the habitable environment, pollution, and others) (Mirkatouli et al. 2015). The result is a degradation of the environment and a reduction in the ability of the environment to provide for and support populations with environmental services (Kalema et al. 2015). This further drives the demand for new spaces from which such environmental services can be derived.

While there has been ongoing interest in the relationship between land degradation and poverty, the complex connections between poverty, declining agricultural productivity, and land degradation still require extensive investigation, especially in developing countries where the objective of meeting food security is still not fully 
achieved (Kirui and Mirzabaev 2014). In 2011, the Food and Agriculture Organization of the United Nations Organization's verdict on the relationship between poverty and land degradation at the global level could not be clearer. It stated, "worldwide, the poorest have the least access to land and water and are locked in a poverty trap of small farms with poor quality soils and high vulnerability to land degradation and climatic uncertainty" (FAO 2011).

\section{Land Degradation and the Provision of Ecosystem Services}

The degradation of land jeopardizes its ability to support local livelihoods through the decreased ability to provide a range of ecosystem services (Global Mechanism of the UNCCD et al. 2019). Land provides society with provisioning services as direct use values, which for example include food, water, fiber, timber, fuel, minerals, building materials and shelter, and biodiversity and genetic resources for producing medicines (ELD Initiative and UNEP 2015). Soils are one of the most important supporting ecosystem services for rural livelihoods. They support many life forms and provide the framework for nutrient cycling that is useful for a range of environmental and livelihood benefits. Forest resources as land-based ecosystem provide carbon sequestration and stock services as a regulating service, which are part of the indirect use value (MEA 2015). Tropical African plants face increasing threats from a wide range of land degradation inducing activities such as fuelwood collection, charcoal production, deforestation for agriculture, and mining. It is estimated that about one-third of all tropical African plant species are potentially threatened by extinction, with another third likely to become threatened soon (Stévart et al. 2019). The top ten countries showing the highest proportion of threatened species include eight countries from West Africa (Benin, Côte d'Ivoire, Gambia, Ghana, Guinea, Liberia, Senegal, and Sierra Leone) along with Ethiopia and Uganda. Given the heavy reliance of these communities on products and services of nature, the degradation or loss of ecosystems and their services has the potential of negatively affecting livelihoods and quality of life. These losses, as is the cases with losses resulting from other forms of land deprivation are likely to have gendered-differentiated impacts for rural communities, with women being disproportionately affected (Yengoh et al. 2015).

The loss of biodiversity, the ecosystems they support, and the ecosystem services they produce will have serious impact for rural communities of sub-Saharan Africa. Biodiversity underpins many livelihoods in drylands, including pastoralism, agriculture and tourism. Nature-based tourism is a particularly important source of income for some rural populations and communities living in sub-Saharan Africa. In recent years, the development and implementation of community-based models of natural resources management, as well as Access, Benefits Sharing schemes have enable local communities to engage positively as natural resources managers (including of protected areas, national parks and nature reserves). These models of comanagement of biodiversity and ecosystems yield positive benefits both for biodiversity conservation and sustainable use, as well as for sustainable livelihoods of rural peoples and communities. The degradation of these resources has the potential to reduce the livelihood and ecosystem services benefits accruing to rural communities.

\section{Land Degradation and Rural Women}

Rural women in many landscapes in SSA areas play a key role in natural resource management and achieving food security. They often grow, process, manage, and market food and other natural resources. Their roles in small livestock, growing food, vegetable gardens, and collecting fuel, fodder, and water has been well documented (Adam and Osbahr 2019; Adeniyi et al. 2016; Yengoh et al. 2015). Women therefore depend heavily on the natural environment to fulfil their traditional roles in society. A healthy environment is not only a foundation for women to successfully meet their traditional obligations, but also for them to achieve and ascertain their financial and decision-making independence. While rural men traditionally engage in agriculture, they tend to grow crops that are commercial in nature as opposed to food crops generally grown by 
women. In Sierra Leone for example, there is a distinction between male crops, such as palm trees for oil, cocoa, coffee, plantains, etc., and female crops such as cassava, maize, beans, vegetables, and others (Yengoh et al. 2015). While women's crops directly contribute to household feeding and nutrition, male crops tend to be for financial income generation to support long-term investments.

Given that women and men have different roles in land use and management, the impact of land degradation affects them in different ways. For example, land degradation from deforestation or desertification increases the amount of time that rural dwellers have to spend gathering fuelwood and fodder and fetching water - activities that are mainly carried out by rural women in sub-Saharan Africa. It reduces food crop yields, hence the quantity and quality of household nutrition (a responsibility of women); reduces the financial and decision-making independence of women; and increases the drudgery of farm manual labor. While men may respond by seeking new farmlands for the household, there is increasing evidence that more men are tending to leave the degraded areas to look for jobs in urban areas, leaving women to assume new roles and responsibilities on the farm (Yengoh et al. 2015).

\section{Land Degradation and Health}

The status of human health is a reflection of a whole variety of complex interactions between the internal biological and the total external environmental system. This supposes that land degradation can affect human health through complex pathways (UNEP 1999). The pathways for human health impacts of land degradation have been the object of scientific interest for a long time. For example, Karr (1997) identified three major multidimensional mechanisms of environmental and human systems alteration with implications for human health. These include: indirect depletion of ecological systems (soil degradation, water supplies degradation, biogeochemical cycles alterations, climate change, ozone layer depletion, and water, air, and soil pollution); direct depletion of non-human living systems (loss of biodiversity, renewable resources exhaustion, pest outbreaks, and spread of alien species); and direct depletion of human systems (epidemics, emerging and reemerging diseases, and reduced quality of life). Healthy ecosystems that are sufficiently stable and biologically diverse tend to maintain the quality of human health, while degraded or severely damaged ecosystems seem to have substantial negative impacts on human health (UNEP 1999). The potential impacts of land degradation on health can include: higher threats of malnutrition from reduced food and water supplies; more water- and food-borne diseases that result from poor hygiene and a lack of clean water; respiratory diseases caused by atmospheric dust from wind erosion and other air pollutants; the spread of infectious diseases as populations migrate (UNEP 1999).

The IPBES estimates that the negative impacts of environmental degradation will affect the wellbeing of at least 3.2 billion people worldwide (IPBES 2018). With specific regard to human health, the report noted that threats, such as water scarcity, are currently affecting about fourfifths of the global population. For rural populations in sub-Saharan Africa, such threat tends to be serious given the limited resources available to procure water from sources outside of communities in which they live. The report also noted that land degradation generally increases the number of people exposed to hazardous air, water, and land pollution, particularly in developing countries. As with the impact of water scarcity, rural populations given their limited access to resources tend to be disproportionately affected. The transformation of natural ecosystems through activities such as clearing, as well as the harvesting and consumption of wild biodiversity can increase the risk of human diseases such as Ebola, monkey pox, Corona virus, and Marburg virus and other deadly pathogens that have recently afflicted human populations (IPBES 2018). In many rural areas of SSA, such as the Congo Basin region and the forest zones of West Africa, rural population depend on bushmeat (wild animals destined for human consumption) and therefore are at higher risks for zoonotic transmission of these deadly diseases. The relationships between environmental health and human mental and physical well-being have 
been well documented. Land degradation generally has the potential of harming psychological well-being by reducing benefits to mental balance, attention, inspiration, and healing (IPBES 2018). It has particularly negative impacts on the mental health and spiritual well-being of indigenous peoples and local communities living in rural areas whose social, cultural, and traditional social structures and belief systems may be centered on environmental relics, processes, or histories.

\section{Institutional and Policy Framework and Initiatives for Addressing Land Degradation in SSA}

Without stemming the causes of land degradation resulting from poor land management, farmers will continue to make the same choices, even at the expense of their future well-being. Hence, the cycle of poor land management will continue to create and sustain higher barriers to agricultural development for rural smallholder farmers and wider economic growth for Africa (The Montpellier Panel 2014). The Africa Resilient Landscapes Initiative (ARLI) is a foundation for building resilient landscapes by bringing agriculture, agroforestry, and rangeland management together. The African Union endorses the initiative, and supports addressing land degradation through the implementation of a range of tested approached such as ecosystem restoration, biodiversity conservation, climate-smart agriculture, and rangeland management. These are vital approaches to reducing land degradation and its impact on rural livelihoods in the region. The World Bank Group and World Resources Institute are main partners, and support the mobilization of financial and technical resources from multiple sources to design and implement country-specific strategies. The African Forest Landscape Restoration Initiative (AFR100) is a country-led effort to bring 100 million hectares of degraded and deforested land in Africa into restoration by 2030. The initiative was launched formally at COP 21 in Paris and aims to promote integrated landscape management and restoration with the goal of adapting to and mitigating climate change. Forests in most of
sub-Saharan Africa are home to many rural and indigenous communities, and the implementation and tare therefore likely to benefit positive outcomes of the AFRI100 initiative. The goal of the TerrAfrica Resilient Landscape Initiative has been working to achieve the restoration of 30 million hectares of land by 30 million households in African landscapes. This initiative targets to develop 30 projects, 30 Country Strategic Investment Frameworks (CSIFs) in sub-Saharan Africa and increase participation to 30 active country members and 30 active partners. The TerrAfrica Business Plan 2016-2020 is the first 5 years of this long-term vision. On-the-ground efforts support among other things the involvement of local communities in the implementation of sustainable landscape and natural resources management. The World Overview of Conservation Approaches and Technologies (WOCAT) has developed standardized tools to enable the global documentation, monitoring, and assessment of soil and water conservation knowledge (Liniger et al. 2011). WOCAT plays an important role in understanding, assessing and providing tools to address challenges on land degradation, as well as to improve land resources and ecosystems (including soils, water, flora, and fauna) and people's livelihoods by sharing, enhancing, and using knowledge on sustainable land management. WOCAT also builds capacity for at all levels for understanding and addressing challenges of land degradation through SLM. Managing and mitigating the effects of land degradation in rural areas have and continue to benefit from WOCAT methodologies, and tools in a number of ways. These include: enhancing land productivity and water use efficiency; improving provisioning of ecosystem goods and services; promoting sustainable use of biodiversity; contributing to food security, and climate change adaptation/ mitigation; and reducing disaster risks and land and water conflicts (Liniger et al. 2011). The challenges addressed by WOCAT are directly relevant for adaptation, innovation, and decision-making around SLM in rural areas worldwide.

For these initiatives to be successful, the specific context of countries, regions, and communities of SSA have to be taken into account. 
These specific conditions which explain the persistence of its agricultural systems, challenges faced in relation to dealing with land degradation, and insights into potential avenues to address when seeking solutions to persistent environmental challenges include:

1. High proportion of drylands (arid, semiarid, and dry subhumid landscapes) that are particularly sensitive to degradation. These are areas with low, infrequent, irregular, and unpredictable precipitation; large variations between day and night-time temperatures; soils containing little organic matter; lack of water; and plants and animals adapted to climatic variables (drought-resistant, salt-tolerant, heat-resistant, and able to cope with a lack of water) (Hori et al. 2011). These drylands make up about $43 \%$ of the region's land surface, account for about $75 \%$ of the area used for agriculture, and are home to about $50 \%$ of the population, including many poor. Involving complex interactions among many factors, vulnerability in drylands is rising, jeopardizing the livelihood for of millions.

2. Substantial number of countries and populations adversely affected by desertification and by the frequent recurrence of severe drought (Hori et al. 2011). One of the most common elements of land degradation-related vulnerability in dryland ecosystems is drought. Population growth and climate change will increase the number of vulnerable people living in drylands, and by 2030 , up to $70 \%$ increase of population vulnerable to drought (Hori et al. 2011).

3. Widespread poverty prevalent in most affected countries, the large number of least developed countries among them, and their need for significant amounts of external assistance, in the form of grants and loans on concessional terms, to pursue their development objectives. About $75 \%$ of Africa's poor (living on less than $\$ 1.25 /$ day) live in countries where people living in drylands make up more than $25 \%$ of total population (Hori et al. 2011).

4. The impact of climate change will exacerbate the effects of some climate-related forms of land degradation on SSA. Results from climate models used to analyze a range of climate change scenarios show that drylands areas will expand and shift as the result of climate change. Some zones might become incapable of sustaining livestock production, rain-fed agriculture, and even intensive agriculture (Hori et al. 2011).

5. Difficult socioeconomic conditions, exacerbated by deteriorating and fluctuating terms of trade (Requier-Desjardins et al. 2011), external indebtedness, and political instability reduce the focus on as well as the availability of resources to dedicate to addressing the impact of land degradation on production and development of rural communities (Nkonya et al. 2016).

6. Heavy reliance of populations on natural resources for subsistence which, compounded by the effects of demographic trends and factors, a weak technological base and unsustainable production practices contributes to serious resource degradation.

7. Insufficient institutional and legal frameworks and the insufficient scientific, technical, and educational capacity (Akhtar-Schuster et al. 2011).

\section{Conclusion}

Land degradation constitutes a huge challenge for sub-Saharan Africa as a region. Its impact has repercussions in all aspects of development and for all of its peoples. For people in rural landscapes who depend directly on land for most of their livelihoods, the impact of land degradation is direct and, in many cases, crucial. The vulnerability of rural livelihoods to land degradation is explained by the heavy reliance of a vast majority of rural populace on agriculture as a means of producing much of household food needs. Their heavy reliance on other land resources such as non-timber forest products for many livelihood needs contributes to their vulnerability to land degradation. Major national and international institutions have recognized the severity of land degradation and its impacts on local populations, 
and initiatives are in place to address this challenge. To succeed in these efforts, it is important to take into consideration some specific characteristics that make the land degradation an intractable problem in sub-Saharan Africa.

\section{Cross-References}

\section{- Community-Based Natural Resources Management \\ - Desertification: Causes and Countermeasures \\ - Ecoregions: Mapping Ecosystems to Protect Biodiversity \\ D Engagement with Trees as "Long-Life Learning" for Sustainability \\ - Environmental Education and Sustainable Development in an Ethical World}

\section{References}

Adam H, Osbahr H (2019) Factors influencing rural livelihood diversification activities among women in northern region of Ghana. Int $\mathrm{J}$ Agric Sci Res Technol (IJASRT) Extens Educ Syst 9(3):115-123

Adeniyi AB, Daud AS, Amao O, Omotayo AO (2016) Determinants of rural Women's livelihood in Ibarapa north local government area of Oyo state, Nigeria. J Hum Ecol 56(1-2):84-90. https://doi.org/10.1080/ 09709274.2016.11907041

Akhtar-Schuster M, Thomas RJ, Stringer LC, Chasek P, Seely M (2011) Improving the enabling environment to combat land degradation: institutional, financial, legal and science-policy challenges and solutions. Land Degrad Dev 22(2):299-312. https://doi.org/10.1002/ ldr. 1058

Barychka T, Mace GM, Purves DW (2020) The Madingley General Ecosystem Model predicts bushmeat yields, species extinction rates and ecosystem-level impacts of bushmeat harvesting. bioRxiv:2020.2003.2002.959718. https://doi.org/ 10.1101/2020.03.02.959718

Beegle K, Christiaensen L (2019) Accelerating Poverty Reduction in Africa. The World Bank, Washington DC. https://doi.org/10.1596/978-1-4648-1232-3

Brown D, Williams A (2003) The case for bushmeat as a component of development policy: issues and challenges. Int For Rev 5(2):148-155. https://doi.org/ 10.1505/IFOR.5.2.148.17414

Cowie AL, Orr BJ, Sanchez VMC, Chasek P, Crossman ND, Erlewein A, Louwagie G, Maron M, Metternicht GI, Minelli S (2018) Land in balance: the scientific conceptual framework for land degradation neutrality. Environ Sci Pol 79:25-35. https://doi.org/ 10.1016/j.envsci.2017.10.011

Eba'a A, Ngouhouo Poufoun J, Mvondo Awono J, Ngoungoure Manjeli A, Sufo Kankeu R (2016) Economic and social importance of fuelwood in Cameroon. Int For Rev 18(1):52-65. https://doi.org/ $10.1505 / 146554816819683735$

ELD Initiative, UNEP (2015) The economics of land degradation in Africa: benefits of action outweigh the costs. Division of Environmental Policy Implementation, United Nations Environmental Programme (UNEP), Nairobi

Eswaran H, Lal R, Reich P (2001) Land degradation: an overview. In: Bridges EM, Hannam ID, Oldeman LR, Pening De Vries FWT, Scherr SJ, Sompatpanit S (eds) Responses to land degradation. Proceedings of 2 nd international conference on land degradation and desertification. Oxford Press, New Delhi, pp 20-35

Fa JE, Olivero J, Farfán MÁ, Márquez AL, Duarte J, Nackoney J, Hall A, Dupain J, Seymour S, Johnson PJ (2015) Correlates of bushmeat in markets and depletion of wildlife. Conserv Biol 29(3):805-815. https://doi.org/10.1111/cobi.12441

FAO (2010a) Forests and energy: regional perspectives: opportunities and challenges for forests and forestry. vol Sixteenth Session. Near East Forestry Commission, Khartoum, Sudan, 18-21. African Forestry and Wildlife Commission, Rome

FAO (2010b) What woodfuels can do to mitigate climate change. vol FAO Forestry Paper 162. Food and Agriculture Organization of the United Nations, Rome

FAO (2011) The state of the world's land and water resources for food and agriculture (SOLAW) - managing systems at risk. Food and Agriculture Organization of the United Nations (FAO)/Earthscan, Rome/London, UK

FAO (2015) Bushmeat sourcebook. Livelihoods. Rome. http://www.fao.org/forestry/wildlife-partnership/ bushmeat-sourcebook/87946/en/

FAO (2020) FAOSTAT statistical database. Food Agriculture Organization of the United Nations, Rome. http:// www.fao.org/faostat/en/. Accessed Mar 2020

FAO, ITPS (2015) Status of the World's Soil Resources (SWSR) - main report. Food and Agriculture Organization of the United Nations Organization, and Intergovernmental Technical Panel on Soils, Rome. http:// www.fao.org/3/a-bc598e.pdf

Gashu K, Muchie Y (2018) Rethink the interlink between land degradation and livelihood of rural communities in Chilga district, Northwest Ethiopia. J Ecol Environ 42(1):1-17. https://doi.org/10.1186/s41610-0180077-0

Global Mechanism of the UNCCD, Conservation International, DIE (2019) Land degradation, poverty and inequality. Global Mechanism of the United Nations Convention to Combat Desertification (UNCCD), Bonn

Heubach K, Wittig R, Nuppenau E-A, Hahn K (2011) The economic importance of non-timber forest products (NTFPs) for livelihood maintenance of rural West 
African communities: a case study from northern Benin. Ecol Econ 70(11):1991-2001. https://doi.org/ 10.1016/j.ecolecon.2011.05.015

Hori Y, Stuhlberger C, Simonett O (2011) Desertification: a visual synthesis. United Nations Convention to Combat Desertification (UNCCD), and Zoï Environment Network, Geneva

International Labour Organization (2020) ILOSTAT database. International Labour Organization, Geneva. https://ilostat.ilo.org/. Retrived Mar 2020

IOM, UNCCD (2019) Addressing the land degradation migration nexus: the role of the United Nations Convention to Combat Desertification. International Organization for Migration (IOM) and United Nations Convention to Combat Desertification (UNCCD), Geneva

IPBES (2018) The IPBES assessment report on land degradation and restoration. Secretariat of the Intergovernmental Science-Policy Platform on Biodiversity and Ecosystem Services, Bonn

Islam T, Ryan J (2015) Hazard mitigation in emergency management. Butterworth-Heinemann, Elsevier, Kidlington

Kalema VN, Witkowski ET, Erasmus BF, Mwavu EN (2015) The impacts of changes in land use on woodlands in an equatorial African savanna. Land Degrad Dev 26(7):632-641. https://doi.org/10.1002/ldr.2279

Karr JR (1997) Bridging the gap between human and ecological health. Ecosyst Health 3:197-199

Kirui OK, Mirzabaev A (2014) Economics of land degradation in Eastern Africa. ZEF working paper series, no. 128. University of Bonn, Center for Development Research (ZEF), Bonn

Liniger H, Mekdaschi R, Hauert C, Gurtner M (2011) Sustainable land management in practice: guidelines and best practices for sub-Saharan Africa. FAO, Rome

MEA (2015) Millennium ecosystem assessment: ecosystems and human well-being: desertification synthesis. World Resources Institute (WRI), Washington, DC

Milner-Gulland EJ, Bennett EL (2003) Wild meat: the bigger picture. Trends Ecol Evol 18(7):351-357

Mirkatouli J, Hosseini A, Neshat A (2015) Analysis of land use and land cover spatial pattern based on Markov chains modelling. City Territory Arch 2(1):1-9. https://doi.org/10.1186/s40410-015-0023-8

Nasi R, Taber A, Van Vliet N (2011) Empty forests, empty stomachs? Bushmeat and livelihoods in the Congo and Amazon basins. Int For Rev 13(3):355-368. https://doi. org/10.1505/146554811798293872

Nkonya E, Johnson T, Kwon HY, Kato E (2016) Economics of land degradation in sub-Saharan Africa. In: Economics of land degradation and improvement-a global assessment for sustainable development. Springer, Cham, pp 215-259

Requier-Desjardins M, Adhikari B, Sperlich S (2011) Some notes on the economic assessment of land degradation. Land Degrad Dev 22(2):285-298. https://doi.org/10.1002/ldr.1056

Shackleton C, Shackleton S (2004) The importance of nontimber forest products in rural livelihood security and as safety nets: a review of evidence from South Africa. S Afr J Sci 100(11):658-664

Stévart T, Dauby G, Lowry P, Blach-Overgaard A, Droissart V, Harris D, Mackinder BA, Schatz G, Sonké B, Sosef MS (2019) A third of the tropical African flora is potentially threatened with extinction. Sci Adv 5(11):eaax9444. https://doi.org/10.1126/ sciadv.aax 9444

Stocking M, Murnaghan N (2001) Handbook for the field assessment of land degradation. Earthscan Publications, London, UK

The Montpellier Panel (2014) No ordinary matter: conserving, restoring and enhancing Africa's soils. A Montpellier panel report. Imperial College London, London, UK

Turner RK, Pearce D, Bateman I (1994) Environmental economics: an elementary introduction. Harvester Wheatsheaf, London, UK

UNCCD (2016) Report of the conference of the parties on its twelfth session, held in Ankara from 12 to 23 October 2015. vol Part two: Actions. ICCD/COP(12)/20/ Add.1. United Nations Convention to Combat Desertification (UNCCD), Bonn. http://www.unced.int/Lists/ OfficialDocuments/cop12/20add1eng.pdf

UNCCD (2017) Global land outlook. United Nations Convention to Combat Desertification (UNCCD), Bonn

UNEP (1999) An assessment of risks and threats to human health associated with the degradation of ecosystems. United Nations Environmental Programme, Nairobi

United Nations Department of Economic and Social Affairs Population Division (2018) World urbanization prospects: the 2018 revision. United Nations Organization, Washington, DC, Online Edition. https://esa.un. org/unpd/wup/Publications

United Nations Department of Economic and Social Affairs Population Division (2019) World population prospects 2019: highlights. vol ST/ESA/SER.A/423. United Nations Organization, Washington, DC

United Nations Organization (2015) Transforming our world: the 2030 Agenda for Sustainable Development [online]. https://sustainabledevelopment.un.org/ post2015/transformingourworld

Vega MG, Carpinetti B, Duarte J, Fa JE (2013) Contrasts in livelihoods and protein intake between commercial and subsistence bushmeat hunters in two villages on Bioko Island, Equatorial Guinea. Conserv Biol 27(3):576587. https://doi.org/10.1111/cobi.12067

Wilkie DS, Starkey M, Abernethy K, Effa EN, Telfer P, Godoy R (2005) Role of prices and wealth in consumer demand for bushmeat in Gabon, Central Africa. Conserv Biol 19(1):268-274. https://doi.org/10.1111/ j.1523-1739.2005.00372.x 
Wilkie DS, Wieland M, Boulet H, Le Bel S, van Vliet N, Cornelis D, BriacWarnon V, Nasi R, Fa JE (2016) Eating and conserving bushmeat in Africa. Afr $\mathrm{J}$ Ecol 54(4):402-414

Yengoh GT, Armah FA, Steen K (2015) Women's bigger burden: disparities in outcomes of large scale land acquisition in Sierra Leone. Gend Issues 32(4):221244. https://doi.org/10.1007/s12147-015-9140-7

Zvoleff AI, Gonzalez-Roglich M, Noon M (2018) Trends. Earth: a platform for using earth observation data in support of the support of the Sustainable Development Goals. In: AGU Fall Meeting Abstracts 